Original Paper

\title{
Pemanfaatan Multimedia dalam Meningkatkan Efektivitas Pembelajaran IPA tentang Sruktur Tanah
}

\author{
Pranoto ${ }^{1^{*}}$ \\ ${ }_{1}^{1}$ Sekolah Dasar Negeri Negeri 2 Bajur, Kabupaten Lombok Barat, NTB, Indonesia
}

DOI: https:// doi.org/10.29303/jcar.v3i1.649

*Corresponding Author:

Pranoto, Sekolah Dasar

Negeri 2 Bajur,

Kabupaten Lombok

Barat, NTB, Indonesia.

Email:

pranoto8c@gmail.com

\begin{abstract}
Abstrak: Tujuan penelitian ini adalah untuk mengetahui bagaimana pemanfaatan Multimedia dapat meningkatkan efektivitas pembelajaran IPA tentang sruktur tanah di Kelas V SDN 2 Bajur Tahun 2017-2018. Jenis penelitian ini yaitu penelitian tindakan kelas dengan langkah-langkah siklus: perencanaan, pelaksanaan, observasi, evaluasi, refleksi. Hasil penelitian menunjukkan bahwa: (1) Dengan mendesain pembelajaran melalui internet sebagai sumber belajar dapat meningkatkan prestasi belajar siswa; (2) Jika guru dapat melaksanakan semua desain pembelajaran yang telah dirancang dengan baik, maka akan berdampak pada peningkatan prestasi belajar siswa; (3) Pembelajaran melalui internet juga sebagai sarana hiburan, sehingga akan menjadi menyenangkan, karena anak kembali ke dunianya; (4) Pembelajaran Melalui internet, mengandung prinsip learning by doing (belajar sambil melakukan sesuatu), trial and refinemen (belajar sambil mengulang-ulang dan berusaha untuk memperbaiki.
\end{abstract}

Kata kunci: Multimedia; Efektivitas Pembelajaran; Struktur tanah; Pembelajaran IPA

\section{Pendahuluan}

Perkembangan ilmu pengetahuan dan teknologi (IPTEK) yang pesat memungkinkan setiap orang memperoleh informasi yang melimpah, cepat, dan mudah dari berbagai sumber dan tempat di dunia (Budiman, 2017). Selain perkembangan yang pesat, perubahan juga terjadi dengan cepat. Karena itu, diperlukan kemampuan untuk memperoleh, mengelola, dan memanfaatkan informasi agar dapat bertahan atau bahkan menyesuaikan diri dengan keadaan yang selalu berubah, tidak pasti, dan kompetitif.

Salah satu bidang yang tidak terlepas dari keberadaan multimedia yaitu bidang pendidikan (Nandi, 2016). Pendidikan adalah salah satu cara untuk dapat menumbuhkan kemauan, kemampuan, dan potensi diri
(Yurnalis, 2016). Pendidikan dapat menjadikan lebih mengerti dan tanggap akan arah dan perubahan serta pengembangan IPTEK. Sejalan dengan diberlakukannya otonomi daerah, sistem pendidikan kita dituntut untuk melakukan perubahan dan penyesuaian sehinga dapat mewujudkan pendidikan yang demokratis, memperhatikan keragaman kebutuhan daerah dan peserta didik (Usman, 2014). Sementara itu, hingga saat ini pendidikan kita masih dihadapkan pada beberapa permasalahan pokok, antara lain perluasan akses pendidikan dan daya saing pendidikan.

Salah satu alternatif pemecahan masalah tersebut yaitu melalui penerapan teknologi pembelajaran, yaitu dengan mendayagunakan sumber-sumber belajar (learning resource) yang dirancang, dimanfaatkan, dan dikelola untuk 
tujuan pembelajaran. Dengan demikian, aplikasi praktis tekhnologi pembelajaran dalam pemecahan masalah belajar mempunyai bentuk konkrit dengan adanya sumber belajar yang memfasilitasi peserta didik untuk belajar. Dalam konteks teknologi pendidikan, sumber belajar merupakan komponen sistem pembelajaran yang merupakan sumbersumber belajar yang dirancang terlebih dahulu dalam proses desain atau pemilihan dan pemanfaatan, dan dikombinasikan menjadi sistem pembelajaran yang lengkap untuk mewujudkan terlaksananya proses belajar yang bertujuan dan terkontrol (Supriadi, 2017; Suhirman, 2018).

SDN 2 Bajur merupakan salah satu Sekolah Dasar di Lombok Barat yang telah memiliki komputer yang telah terkoneksi multimedia. Namun, dalam kegiatan belajar mengajar mata pelajaran IPA di SDN 2 Bajur belum memanfaatkan multimedia sebagai sumber belajarnya. Disamping itu juga perilaku siswa menjadi kurang percaya diri baik dalam bertanya, menyampaikan ide maupun dalam proses pemecahan masalah yang dihadapi.

Berdasarkan uraian tersebut dilakukan penelitian dengan judul "Pemanfaatan Multi media Dapat Meningkatkan Efektivitas Pembelajaran IPA Tentang Sruktur Tanah Kelas V SDN 2 Bajur Tahun 2017-2018".

\section{Metode}

\section{Setting Penelitian}

Tempat penelitian ini di SDN 2 Bajur siswa-siswi kelas $\mathrm{V}$ yang berjumlah 30 orang. Komposisi laki-laki 16 orang dan perempuan 14 orang. Dari ke 30 siswa tersebut mereka berasal dari keluarga tidak mampu, mata pencaharian orang tuanya sebagian besar sebagai buruh dan tani. Perhatian orang tua terhadap pendidikan anak-anaknya sangat kurang. Bimbingan orang tua yang sangat minim inilah yang menjadi sumber rendahnya minat dan prestasi siswa. Penelitian ini dilakukan selama tiga bulan dari bulan Januari sampai bulan Maret. Subjek penelitian ini adalah kelas V SDN 2 Bajur tahun pelajaran 2017/2018 terdiri dari 30 siswa, 16 laki-laki dan 14 orang perempuan

\section{Variabel yang Diteliti}

a. Variabel tindakan pemanfaatan internet sebagai sumber belajar dalam pembelajaran IPA kelas V SDN 2 Bajur.

b. Variabel harapan/Output, Peningkatan motivasi belajar pada mata pelajaran IPA.

\section{Indikator Penelitian}

Indikator keberhasilan yang di jadikan acuan pada Penelitian Tindakan Kelas (PTK) ini adalah a). Pencapaian nilai siswa di atas Kreteria ketuntasan Minimal (KKM) yang telah di tetapkan yaitu 70; b). Prosentase keberhasilan ketuntasan Kelasikal siswa $75 \%$ dari jumlah siswa.

\section{Rencana Penelitian}

Secara ringkas tahap-tahap kegiatan dalam penelitian tindakan kelas ini adalah:

Pada setiap siklus masing-masing dilaksanakan 1 kali pertemuan dengan langkah-langkah siklus: perencanaan, pelaksanaan, observasi, evaluasi, dan refleksi. Pada tahap refleksi peneliti merenungkan kembali tahapan-tahapan yang dilakukan oleh guru terhadap siswa pada semua kelemahankelemahan yang ditemukan akan menjadi dasar perbaikan pada siklus berikutnya.

\section{Instrumen Penelitian}

Instrument atau alat yang digunakan untuk mengumpulkan data pada penelitian tindakan kelas ini yaitu lembar observasi aktifitas guru dan siswa dan tes hasil belajar.

\section{Pengumpulan Data}

Data hsil belajar siswa diperoleh melalui metode pemberian tes pada setiap siklus. Data hasil belajar digunakan untuk mengetahui pemahaman siswa terhadap materi yang telah diajarkan pada setiap siklus. 
Data hasil observasi diperoleh melalui pengamatan langsung oleh pengamat dalam tiap pertemuan di kelas. Observer untuk aktivitas guru selama proses pembelajaran adalah rekan guru, sedangkan observer untuk aktivitas belajar siswa adalah peneliti. Observasi dilakukan untuk mengetahui aktivitas guru dan siswa selama proses pembelajaran berlangsung.

\section{Analisis Data}

1. Data Hasil Belajar Siswa

Data tentang hasil belajar siswa dianalisis secara deskriftif kuantitatif. Hasil belajar yang dicapai siswa setelah proses pembelajaran pada penelitian ini berupa ketuntasan individu, nilai rata-rata hasil belajar siswa dan persentase ketuntasan klasikal. Adapun rmus-rumus yang digunakan sebagai berikut: Ketuntasan Individu. Nilai rata-rata siswa. Persentase ketuntasan klasikal

\section{Data Aktivitas Belajar Siswa}

Aktivitas siswa dapat diketahui melalui observasi terhadap prilaku siswa selama mengikuti pembelajaran dengan lembar observasi terdiri dari empat indikator dan tiap indiator terdiri dari empat deskriptor.

\section{Data Aktivitas Guru.}

Data aktivitas guru dianalisis secara kwalitatif dengan cara mengidentifikasi deskriptor-deskriptor yang belum nampak pada proses pembelajaran. Setelah mengetahu deskriptor-deskriptor yang belum nampak guru dapat menganalisis penyebabnya untuk mencari solusi dan merencanakan pembelajaran yang lebih baik pada siklus berikutnya.

\section{Hasil dan Pembahasan}

\section{Siklus I}

\section{Perencanaan}

Pada tahap ini peneliti melakukan perencanaan siklus I diantaranya: a) Peneliti mempersiapkan alat peraga (media) yang sesuai dengan materi yaitu: laptop, LCD, speaker; b) Peneliti mempersiapkan/ menyusun Lembar Kerja Siswa (LKS); c) Guru menyusun alat evaluasi; d) Guru melakukan simulasi pembelajaran yang telah disusun dan dicobakan di kelas lain.

\section{Pelaksanaan}

Langkah-langkah pelaksanaan perbaikan pembelajaran mata pelajaran IPA adalah: 1) Guru mengadakan apersepsi dengan mempertanyakan kepada siswa materi sebelumnya; 2) Guru menginformasikan tujuan pembelajaran sesuai dengan topik pada hari itu; 3) Guru memutarkan video tentang teori big bang (terbentuknya alam semesta yang disebabkan karena ledakan yang hebat); 4) Guru membimbing siswa dalam merumuskan masalah; 5) Guru menggali pengetahuan awal siswa; 6) Guru memberikan penjelasan dengan menggunakan power point; 7) Guru membagi beberapa siswa menjadi 5 kelompok; 8) Guru membimbing siswa dalam melakukan percobaan. 9) Kegiatan akhir: Guru membuat rangkuman materi sebagai catatan untuk siswa kemudian guru mengumpulkan LKS dan guru menutup pelajaran.

\section{Hasil Perbaikan Pembelajaran}

Hasil perbaikan pembelajaran dijelaskan seperti Tabel 1.

Tabel 1. Hasil Ketuntasan belajar siswa Siklus I

\begin{tabular}{|c|c|c|c|c|}
\hline \multirow[b]{2}{*}{ No } & \multirow[b]{2}{*}{$\begin{array}{l}\text { Rentang } \\
\text { Nilai }\end{array}$} & \multicolumn{3}{|c|}{ SIKLUS I } \\
\hline & & $\begin{array}{l}\text { Jml } \\
\text { Siswa }\end{array}$ & $(\%)$ & KET \\
\hline 1. & $\begin{array}{l}\text { 6,5 sampai } \\
\text { dengan } 10\end{array}$ & 19 & 63,3 & Tuntas \\
\hline 2. & $\begin{array}{l}5,5 \text { sampai } \\
\text { dengan } 64,9\end{array}$ & 5 & 16,3 & $\begin{array}{l}\text { Tdk } \\
\text { tuntas }\end{array}$ \\
\hline 3. & $\begin{array}{l}54,9 \text { ke } \\
\text { bawah }\end{array}$ & 6 & 20 & $\begin{array}{l}\text { Tdk } \\
\text { tuntas }\end{array}$ \\
\hline & Total & 30 & & \\
\hline
\end{tabular}

Deskripsi data ketuntasan belajar siswa pada mata pelajaraan IPA Siklus I: Rentang nilai 6,5 s/d 10 diraih oleh 19 siswa dari 30 siswa prosentase ketercapaian $63,3 \%$ nilai di atas KKM. 
Data kegiatan pelaksanaan pembelajaran guru dengan menggunakan internet pada mata pelajaran IPA siklus I menunjukkan bahwa: dari 42 deskriptor dan 12 Indikator, maka baru 18 deskriptor yang bisa tercapai, atau setara dengan $41,1 \%$ saja. Hal ini disebabkan adanya beberapa kendala yaitu ketika kegiatan pembejaran berlangsung tibatiba kelas kedatangan tamu seorang pengawas, sehingga perhatian anakpun juga terganggu dan waktu sudah berkurang.

Data dari lembar pengamatan (Observasi) tentang kegiatan siswa selama dalam pembelajaran untuk mengetahui tingkat motivasi siswa terhadap proses pembelajaran. Dari 15 indikator/aspek yang diharapkan dapat dikuasai oleh anak, ternyata baru 36 indikator yang bisa terlaksana atau sama dengan $60 \%$, sehingga jika kita melihat indikator kinerja, maka tingkat motivasi siswa masih tergolong rendah, pada indikator ( butir 10), siswa masih sering mengeluh jika mendapatkan kesulitan( mudah putus asa) sehungga berdampak pada prestasi belajar siswa.

\section{Refleksi}

Pada siklus I ada beberapa hal yang perlu diperbaiki seperti: 1) Guru harus mempersiapkan alat-alat yang diperlukan sebelum kegiatan dimulai; 2) Guru sebaiknya mencoba terlebih dahulu alat/media yang akan digunakan; 3) Guru harus terlebih dahulu menertibkan murid; 4) Guru harus memberikan kesempatan kepada siswa lain untuk menjawab atau menanggapi apa yang dilakukan oleh temannya yang ada di depan kelas; 5) Kesempatan atau waktu untuk tanya jawab sebaiknya diperbanyak; 6) Guru harus menugaskan kepada siswa lain, secara berpasangan dengan teman sebangkunya untuk melakukan peragaan seperti yang telah dicontohkan oleh temannya di depan kelas; 7) Pembimbingan secara kelompok lebih diintensifkan; 8) Guru harus memberikan penekanan-penekanan tentang materi yang telah dipelajari pada akhir pelajaran.

\section{Siklus II}

\section{Perencanaan}

Pada tahap kedua peneliti melakukan perencanaan dengan mengacu pada temuantemuan siklus I. diantaranya: a) Peneliti mempersiapkan alat peraga (media) yang sesuai dengan materi yaitu: laptop, LCD, speaker; b) Peneliti mempersiapkan/ menyusun Lembar Kerja Siswa (LKS); c) Guru menyusun alat evaluasi; d) Guru melakukan simulasi pembelajaran yang telah disusun dan dicobakan di kelas lain.

\section{Pelaksanaan}

Dengan berpegang pada rencana pelaksanaan perbaikan pembelajaran mata pelajaran IPA sebagai berikut: Guru mengadakan apersepsi dengan mengulang materi sebelumnya. Guru menjelaskan tujuan pembelajaran sesuai dengan topik pada hari itu. Guru menayangkan video terbentuknya alam semesta. Guru membimbing siswa dalam dalam melakukan percobaan. Guru memperhatikan perkembangan siswa dalam berdiskusi kelompok, guru memberikan kesempatan siswa untuk mempersentasekan tugasnya. Kegiatan akhir: Guru membuat rangkuman materi sebagai catatan untuk siswa. Guru mengumpulkan LKS. Guru menutup pelajaran.

\section{Hasil Perbaikan Pembelajaran}

Hasil perbaikan pembelajaran pada siklus II, dijelaskan pada Tabel 2.

Tabel 2. Hasil Ketuntasan belajar siswa Siklus II

\begin{tabular}{lllll}
\hline \multirow{2}{*}{ No } & \multirow{2}{*}{$\begin{array}{l}\text { Rentang } \\
\text { Nilai }\end{array}$} & $\begin{array}{l}\text { SIKLUS II } \\
\text { Siswa }\end{array}$ & $(\%)$ & Ket \\
\hline 1. & 6,5 sampai & 25 & 83,3 & Tuntas \\
& dengan 10 & & $\%$ & \\
2. & 5,5 sampai & 5 & 16,7 & Tdk \\
& dengan 64,9 & & $\%$ & tuntas \\
3. & 54,9 ke & - & - & \\
& bawah & & & \\
& Total & 30 & & - \\
\hline
\end{tabular}


Deskripsi data ketuntasan belajar siswa pada mata pelajaraan IPA Siklus II yaitu Rentang nilai $6,5 \mathrm{~s} / \mathrm{d} 10$ diraih oleh 25 siswa dari 30 siswa ketercapaian 83,3\%nilai di atas KKM. Rentang nilai 5,5 s/d 6,49 diraih sebanyak 5 siswa dari 30 siswa prosentase ketercapaian 16,7\% nilai di bawah KKM. Rentang nilai 5,49 ke bawah kosong atau tidak ada siswa yang mendapatkan nilai dibawah 5,49 .

Data kegiatan pelaksanaan pembelajaran guru mata pelajaran IPA dengan menggunakan internet pada siklus II menunjukkan peningkatan yang cukup baik antara lain: pada indikator (2) pengelolaan kelas, kegiatan pelayanan guru terhadap siswa cukup bervariasi yaitu, individu, berpasangan, maupun kelompok sehingga berdampak pada pencapaian indikator nomor (12) yaitu hasil belajar siswa sebagaian besar memenuhi Kreteria Ketuntasan Minimal.( KKM) yaitu 70.

Indikator nomor (5) dan (9) mengalami peningkatan yaitu guru pada siklus ke 2 ini sudah mampu melibatkan peserta didik dengan maksimal, juga sudah melaksanakan pembelajaran dengan menggunakan multi media, laptop, LCD, bahkan menayangkan sebuah video untuk menarik minat belajar siswa.

Data dari lembar hasil observasi kegiatan pembelajaran siswa pada siklus II. Terjadi perubahan yang menunjukan peningkatan yang lebih baik, misal pada indikator nomor (3), setelah guru menampilkan beberapa materi dari internet maka rasa ingin tahu, rasa penasaran siswa cukup tinggi. Indikator nomor (10), sebelumnya siswa merasa cepat putus asa dalam mengerjakan tugas, ternyata setelah guru memberi tahu cara mencari pemecahan masalah lewat internet, maka siswa selalu senang dan bahkan sering mencari sendiri materi materi tambahan, jika dirasa materi yang ada pada buku paket belum cukup. Hal ini menunjukkan motivasi siswa cukup tinggi jika memanfaatkan internet sebagai salah satu sumber belajar. Dan akan berdampak pada peningkatan prestasi belajar anak.

\section{Refleksi}

Simpulan Penulis pada pembelajaran di siklus II ini, rencana kegiatan yang telah dibuat oleh guru sudah dapat dilaksanakan sesuai dengan sistimatikanya, tahapantahapan pembelajaran sudah sangat rinci dan jelas, sehingga aspek aspek yang akan dikuasai oleh siswa dapat diukur dengan menggunakan alat evaluasi yang berupa tes. Guru lebih banyak memberikan LKS yang bersifat terbuka, agar siswa semakin luas dalam memberdayakan potensi pada diri anak dalam bernalar. Guru memperbaiki pada kegiatan pembelajaran pada kesempatan yang lain.

Pelaksanaan perbaikan pembelajaran dengan memanfaatkan internet sebagai salah satu sumber belajar di kelas V SDN 2 Bajur pada siklus I dapat dikatakan belum berhasil, hal ini dapat kita lihat dari indicator kinerja yang menjadi acuan dalam penelitian ini. Beberapa hal menurut penulis yang menjadi penyebab belum berhasil adalah:

1. Guru sering tidak menginformasikan tujuan pembelajaran di awal kegiatan.

2. Guru kurang menggali pengetahuan awal siswa untuk mengetahui kemampuan dasar yang dimiliki oleh siswa.

3. Guru kurang mengaitkan materi pembelajaran dengan pengalaman siswa sehari-hari.

4. Guru kurang memberikan bimbingan dalam pengisian LKS, sehingga anak cenderung mengisi menurut kemauannya sendiri( kurang terarah).

5. Guru sering tidak memberikan rangkuman materi sebagai catatan siswa.

6. Guru kurang membimbing siswa dalam menyusun kesimpulan.

Pelaksanaan kegiatan perbaikan pembelajaran pada siklus II, sudah dapat dikatakan berhasil, jika dilihat dari indicator kinerja (KKM dan prosentase ketercapaian pelaksanaan kegiatan guru dan murid). Guru 
telah dapat melaksanakan semua kegiatan dengan baik, sehingga berdampak pada tercapainya ketuntasan belajar siswa, yaitu KKM 70 dan jumlah ketercapaianya $75 \%$. Dalam kegiatan pembelajaran dengan memanfatkan internet sebagai salah satu sumber belajar siswa dapat meningkatkan motivasi dan aktivitas sesuai dengan tujuan yang diharapkan. Berbagai potensi siswa akan berkembang melalui aktivitas antara lain: a) Apa yang siswa lihat; b) Apa yang siswa dengar; c) Apa yang siswa sentuh; d) Apa yang siswa rasakan; e) Apa yang siswa baui; f) Apa yang siswa lakukan.

\section{Kesimpulan}

Berdasarkan hasil penelitian, disimpulkan bahwa dengan mendesain pembelajaran melalui internet sebagai sumber belajar dapat meningkatkan prestasi belajar siswa. Jika guru dapat melaksanakan semua desain pembelajaran yang telah dirancang dengan baik, maka akan berdampak pada peningkatan prestasi belajar siswa. Pembelajaran melalui internet juga sebagai sarana hiburan, sehingga akan menjadi menyenangkan, karena anak kembali ke dunianya. Pembelajaran melalui internet, mengandung prinsip learning by doing (belajar sambil melakukan sesuatu), trial and refinemen (belajar sambil mengulang-ulang dan berusaha untuk memperbaiki).

\section{Daftar Pustaka}

Budiman, H. (2017). Peran Teknologi Informasi Dan Komunikasi Dalam Pendidikan. Al-Tadzkiyyah: Jurnal Pendidikan Islam, 8(1), 31. https://doi.org/10.24042/atjpi.v8i1.2095

Nandi, N. (2016). Penggunaan Multimedia Interaktif Dalam Pembelajaran Geografi Di Persekolahan. Jurnal Geografi Gea, 6(2). https://doi.org/10.17509/gea.v6i2.1741

Suhirman, S. (2018). Pengelolaan Sumber Belajar Dalam Meningkatkan Pemahaman
Peserta Didik. Al Fitrah: Journal Of Early Childhood Islamic Education, 2(1), 159. https://doi.org/10.29300/alfitrah.v2i1.15 13

Supriadi, S. (2017). Pemanfaatan Sumber Belajar Dalam Proses Pembelajaran. Lantanida Journal, 3(2), 127. https:// doi.org/10.22373/lj.v3i2.1654

Usman, A. S. (2014). Meningkatan Mutu Pendidikan Melalui Penerapan Manajemen Berbasis Sekolah. Jurnal Ilmiah Didaktika, 15(1), 13. https://doi.org/10.22373/jid.v15i1.554

Yurnalis. (2016). Motivasi belajar sebuah strategi mengungkap potensi kecerdasan intelegensi dan emosi. Jurnal Risalah, 27(1), 46-55. 